\title{
REVIEW OF SOME TRADITIONAL HERBALS INCLUDED IN USADA TENUNG TANYA LARA AS DIARRHEA THERAPY AGENTS
}

\author{
I Kadek Suardiana ${ }^{1}$, A.A Gede Rai Yadnya-Putra ${ }^{1 *}$ \\ ${ }^{1}$ Department of Pharmacy, Faculty of Mathematics and Science, Udayana University \\ Corresponding author email: agungryp@unud.ac.id
}

\begin{abstract}
Background: Diarrhea is one of the most extraordinary diseases in the world, with a number of 2.195 children die every day, and 801.000 children die from diarrhea every year. Diarrhea therapy has actually been conducted by society, but the use of synthetic drugs is limited for diarrhea cases since it will trigger undesirable effects, such as abdominal pain and resistance to pathogenic bacteria. Bali, with its unique culture, has Usada Tenung Tanya Lara, which contains procedures for treating diarrhea using plants. Objective: This work aimed to review traditional medicine, which is written in Usada Tenung Tanya Lara, that has been intensified nowadays and can be an alternative in the treatment of diarrhea. Methods: This article review using a primary data source and secondary data sources. Results: Some of the plants that have been collected have anti-diarrheal activity in the usada Tenung Tanya Lara are turmeric (Curcuma longa), banana (Musa paradisiaca) and ancak (Ficus religiosa). These three plants mostly have anti-diarrheal activity by inhibiting and killing pathogenic bacteria that cause diarrhea, such as Shigella dysenteriae, Escherichia coli, and Vibrio cholerae. Aside from being antibacterial, all three plants also have several mechanisms to cure diarrhea. Conclusion: It was revealed that turmeric, banana, and ancak leaf could act as agents of diarrhea therapy with their respective mechanisms of actions.
\end{abstract}

Keywords: Diarrhea, Usada Tenung Tanya Lara, Curcuma longa, Musa paradisiaca, Ficus religiosa.

\section{INTRODUCTION}

Diarrhea is bowel movements with a consistency of a liquid or semi-liquid stool, which contains more water than the usual (>200 grams or $200 \mathrm{~mL} / 24$ hours) and can be accompanied by or without slime and blood desiccation ${ }^{[1]}$. The latest data compiled by the Centers for Disease Control $^{[2]}$, diarrheal diseases including extraordinary events in the world, whereas many as 2.195 children die every day and 801.000 children per year die from diarrhea. Dehydration due to diarrhea is an important cause of death in children ${ }^{[3]}$. The CDC data above illustrates that diarrhea is still one of the most common health problems in the world, especially in developing countries with low living standards, such as in Indonesia ${ }^{4}$. The Ministry of Health of the Republic of Indonesia ${ }^{[5]}$ states that diarrhea is the second highest cause of infant mortality in Indonesia after pneumonia. Diarrhea caused $11 \%$ of under-five deaths based on data from the Ministry of Health of the Republic of Indonesia in 2018, which has increased by $8,6 \%$ over the past five years (2013 data showed a mortality rate of $2,4 \%)$.

Risk factors can cause an increase in diarrhea rates, including environmental sanitation, which includes the provision of clean water, waste management, wastewater disposal facilities, and personal hygiene, such as washing hands ${ }^{[6]}$. 
Generally, the most common cause of diarrhea is infectious diarrhea, where infectious diarrhea can be caused by viruses, bacteria, and parasites. Bacteria that can cause diarrhea are Shigella dysenteriae, Shigella sonnei, Escherichia coli, Vibrio cholerae, and Shigella flexner, where $S$. dysenteriae, E. coli, and $V$. cholerae are the main causes of diarrhea which results in a high mortality rate ${ }^{[7]}$. Other factors cause death due to diarrhea, namely dehydration, due to loss of fluid and electrolytes during diarrhea through feces. Generally, infants who experience prolonged diarrhea will cause dehydration. Dehydration due to diarrhea depends on the percentage of body fluids lost. Dehydration of diarrhea that occurs is categorized into diarrhea without dehydration, mild/ moderate, and severe dehydration ${ }^{[8]}$.

Diarrhea therapy has been guided by the available literature, such as WHO diarrhea treatment guidelines, important medicines book by Tjay and Rahardja, and MIMS Diarrhea is essentially healed in less than five days, so it is recommended not to be given medication because at that time the damaged mucosal epithelial cells are replaced by new cells, but if severe diarrhea can be used symptomatic drugs such as tannic acid (tannalbin), aluminum hydroxide and absorbent carbon ${ }^{[3]}$. However, the use of synthetic drugs is limited for diarrhea sufferers because it will have undesirable effects, such as loperamide should be avoided in bloody diarrhea or suspected inflammation, or when associated with significant abdominal pain $^{[9]}$.

WHO guidelines in 2005 were updated in $2016^{[10]}$, which discussed that treatment for diarrhea infected by pathogenic bacteria could be treated using antibiotics, with ciprofloxacin as its first line. Pivmecillianam antibiotics (amdinocillin pivoxil) and ceftriaxone can also be used, where these antimicrobials are effective for the treatment of Shigella multi-resistance strains in all age groups. However, their use is limited because of the high cost and difficulty of formulation, and the use of this drug is only intended when the local strain of Shigella is resistant to ciprofloxacin. The second line that can be recommended is Azithromycin, but its use is not recommended for children due to a lack of safety data usage.

Based on the presence of several complications during therapy, such as drug resistance, it encourages researchers to find alternatives to tackle the problem of diarrhea. Nowadays, traditional medicine or ethnomedicine has been intensified. Ethnomedicine is a treatment that is based on local wisdom and is carried out empirically or hereditary. The local wisdom in question is the cultural wealth of the local community, especially regarding traditional medical systems. In Indonesia, especially in Bali, there is a well-known traditional medicine system known as indigenous lontar, which is known as Usada Bali. Lontar Usada Bali is a script about the system of medicine, herbs, and traditional Balinese methods of treatment ${ }^{[11]}$. Usada treatment in Bali is based on Ayurveda medicine and ancient medical manuscripts in Bali $^{[12]}$.

The treatment of diarrhea itself (or better known as mencret in Usada Bali papyrus) using various herbs and mantras has been widely discussed in Usada Bali, especially in Usada Tenung Tanya Lara papyrus. In this papyrus, many types of treatment with herbs and spells are offered for various types of diarrhea ${ }^{[13]}$. However, in Usada Tenung Tanya Lara papyrus did not explain the mechanism of its activity can be used as therapy in diarrheal diseases. The number of herbs will certainly confuse the reader in using which herbs to use in his therapy.

Based on the problems outlined above, the writer is interested in discussing some of the herbs used in Usada Tenung Tanya Lara as diarrhea therapy and aims to facilitate the public in choosing herbs for diarrhea therapy. 


\section{METHODS}

The primary data source was obtained from the derivation of Usada Tenung Tanya Lara papyrus by Sudiasta and Suwidja (1991). The process of finding secondary data sources is obtained by searching on google, google scholar, and NCBI with the keywords "diarrhea", "treatment ofdiarrhea", "anti-diarrheal activity in turmeric (Curcuma longa)", "anti-diarrheal activity on bananas (Musa paradisiaca)" "anti-diarrheal activity on ancak (Ficus religiosa) " and " anti-diarrhea activity in plants ". Secondary data sources used are journals that have been published for the past ten years. The use of data over the last ten years is applied if no last ten years of data is supported.

\section{RESULTS}

The results obtained from primary data sources in the form of derivation Usada Tenung Tanya Lara are several herbs that have activities as diarrhea therapy agents in the form of plant names in Usada Tenung Tanya Lara, the plant parts used, and how to use them, while pharmacological activities were obtained from various data sources in this review. The results obtained from these primary data sources are listed in Table 1.

\section{DISCUSSION}

\section{Overview of the Antidiarrheal Effects of Turmeric}

Turmeric has long been used in traditional medicine. Curcumin is a lipophilic polyphenol compound ${ }^{[14]}$. Curcumin, an active compound in turmeric, has several health benefits, which is useful as an antioxidant and anti-inflammatory ${ }^{[15]}$. In Usada Tenung Tanya Lara, turmeric ( $C$. longa) can be used to cure diarrhea. Based on the research, turmeric methanol extract at a dose of $100 \mathrm{mg} / \mathrm{kg} \mathrm{BW}$ and $200 \mathrm{mg} / \mathrm{kg}$ BW have a significant inhibitory effect on intestinal motility, where the parameters being observed were the amount of dry and wet stool in diarrhea cases ${ }^{[16]}$. Observation of intestinal motility needs to be considered, considering that in classical theory, diarrhea is caused by an increase in intestinal peristaltic so that the passage of the chymus is greatly accelerated and in this condition, there is still a lot of water ${ }^{3}$. In vivo studies in mice showed that $C$. longa extract could reduce contractions in the ileal smooth muscle and large intestine ${ }^{[17]}$.

Turmeric has also been reported to have antibacterial activity, especially against pathogenic bacteria that cause diarrhea, namely E. coli and V. cholera. For screening, it was preliminary found that some turmeric extract was able to inhibit the growth of pathogenic bacteria by observing the inhibitory zone. In E. coli, turmeric ethanol extract produces inhibition zones are $8 \mathrm{~mm}$ and $25 \mathrm{~mm}^{[18,19]}$ and ethyl acetate extract produces inhibition zones of 25 $\mathrm{mm}^{[19]}$, whereas, in $V$. cholerae, ethanol extract produces $20 \mathrm{~mm}$ inhibition zones and ethyl acetate extract produces $25 \mathrm{~mm}$ inhibition zones ${ }^{[19]}$. Further research was carried out to obtain the MIC value of pathogenic bacteria, wherein $E$. coli bacteria; ethanol extract produced a value of $0,006 \mu \mathrm{g} / \mathrm{mL}-5 \mu \mathrm{g} / \mathrm{mL}^{[19,20]}$. Treatment of diarrhea caused by gram-negative bacteria can be combined with antibiotic therapy, such as ciprofloxacin which can inhibit and kill the growth of gram-negative bacteria, such as E. coli and V. cholera $^{[3]}$ so that the MIC results can be interpreted with the antibiotic approach used. Ciprofloxacin has a limit on the MIC value of the category susceptible in the area under $5 \mu \mathrm{g} / \mathrm{mL}$, so it can be stated that the turmeric extract susceptible against bacteria $E$. coli and $V$. cholera $^{[21]}$.

\section{Overview of the Antidiarrheal Effects of Banana Plants (Musa paradisiaca)}

In Usada Tenung Tanya Lara, the banana part used is the root. However, there is little literature that states that banana roots can potentially be anti-diarrheal. The main compound in bananas that acts as a 


\begin{tabular}{|c|c|c|c|c|c|c|}
\hline No & $\begin{array}{l}\text { Plant's } \\
\text { name in } \\
\text { Usada }\end{array}$ & $\begin{array}{c}\text { Indonesian } \\
\text { Name }\end{array}$ & $\begin{array}{l}\text { Scientific } \\
\text { Name }\end{array}$ & $\begin{array}{l}\text { Parts } \\
\text { Plant } \\
\text { Used }\end{array}$ & $\begin{array}{c}\text { Indications } \\
\text { Diarrhea }\end{array}$ & How to Use \\
\hline 1 & Kunir & Kunyit & $\begin{array}{l}\text { Curcuma } \\
\text { longa }\end{array}$ & Bulb & $\begin{array}{l}\text { Diarrhea as if } \\
\text { pouring }\end{array}$ & $\begin{array}{l}\text { Bulbs of turmeric } \\
\text { combine with ampo and } \\
\text { the juice is drunk }\end{array}$ \\
\hline 2 & Biu sepet & Pisang & $\begin{array}{c}\text { Musa } \\
\text { paradisiaca }\end{array}$ & Root & Diarrhea out water & $\begin{array}{l}\text { Roots of biu sepet } \\
\text { pounded by onion and } \\
\text { fennel, squeezed, water } \\
\text { is taken }\end{array}$ \\
\hline 3 & Ancak & Bodhi & $\begin{array}{l}\text { Ficus } \\
\text { religiosa }\end{array}$ & Leaf & $\begin{array}{l}\text { Diarrhea with } \\
\text { feces expenditure } \\
\text { volume gradually } \\
\text { (ngecer) }\end{array}$ & $\begin{array}{l}7 \text { leaves of ancak } \\
\text { combine with ireng salt } \\
\text { and then poured boiling } \\
\text { hot water, the water is } \\
\text { drunk }\end{array}$ \\
\hline
\end{tabular}

therapy for diarrhea is Pectin ${ }^{[22]}$. Several studies have described the presence of Pectin in bananas. Hot water extract of the banana root has a MIC value of $100 \mathrm{mg} / \mathrm{mL}$ for $E$. coli. Hot water extract of the banana root contains secondary metabolites of alkaloids, flavonoids, saponins, glycosides, and antraquinone ${ }^{[23]}$. Other studies reveal that other parts of banana plants can potentially be anti-diarrheal regardless of the part mentioned in Usada Tenung Tanya Lara.

The leaf of bananas contains secondary metabolites that are similar to the roots, namely alkaloids, saponins, tannins, glycosides, flavonoids, carbohydrates, and terpenoids. The difference lies in the absence of anthraquinone compounds in banana leaf. The curve time-kill in ethanol extract of the banana leaf shows the ability of the extract to reduce the micro population exponentially with time, where one of the bacteria tested was the pathogenic bacterium that causes diarrhea, $S$. dysenteriae $^{[24]}$. Sap and banana peels have also been reported to function as antidiarrheal. Research on these two parts of the banana plant uses an in vivo approach to Wistar rats induced by castor oil. The antidiarrheal activity of banana sap is associated with the presence of secondary metabolites of alkaloids, phenolics, flavonoids, and saponins, which can increase the absorption of fluids and electrolytes through de novo synthesis of sodium-potassium ATPase and/ or reducing nitriloside levels ${ }^{[25]}$. Meanwhile, banana peel can influence the consistency of water in the stool, where the concentration of water in the stool can be reduced and significantly has the same effect on attapulgite on the ethanol extract concentration of banana peels at $400 \mathrm{mg} / \mathrm{kg}$ $\mathrm{BW}^{[26]}$. The pectin content in banana peels ranges from $13,5 \%$ to $24,08 \%$ [27,28,29,30].

Clinical testing of bananas has long been carried out, based on research reports by Rabbani ${ }^{[22]}$, in which studies of babies aged 5-12 months who have diarrhea. Giving food mixed with $250 \mathrm{~g} / \mathrm{L}$ cooked green banana fruit and $4 \mathrm{~g} / \mathrm{kg}$ pectin showed significant results in reducing total stool, oral rehydration fluids, intravenous fluids in the body, vomiting, and duration of diarrhea on the third day after giving pectin-rich foods, and experienced an increase in the percentage of diarrheal therapy parameters on the fourth day. In terms of toxicity, bananas tested for sub-acute toxicity do not cause toxic effects if consumed up to 800 $\mathrm{mg} / \mathrm{kg} \mathrm{BW}$ daily ${ }^{[31]}$.

\section{Overview of the Antidiarrheal Effects of Ancak (Ficus religiosa)}

Ancak ( $F$. religiosa) in the book of Ayurveda has been well-known as an ethnomedicinal agent. In northern India itself, the decoction of ancak leaf mixed with honey is used to treat diarrhea ${ }^{[32]}$. Part of the leaf in Lontar Usada Tenung Tanya 
Lara has also been mentioned to have efficacy as a diarrhea therapy agent. Phytochemicals, ancak leaf contains campesterol, stigmasterol, iso-phytosterols, a-amyrin, lupeol, tannic acid, arginine, serine, aspartic acid, glycine, threonine, alanine, proline, tryptophan, tyrosine, methionine, valine, isoleucine, serine, aspartic acid, glycine, threonine, alanine, proline, tryptophan, tyrosine, methionine, valine, isoleucine, leine, and nnonacosane ${ }^{[33,34,35,36]}$. Various studies have been carried out on the pharmacological activity of the ancak leaf as a therapeutic agent of diarrhea, especially diarrhea caused by a bacterial infection. The methanol and ether extract of ancak leaf able to provide antibacterial activity as pathogenic $E$. coli $^{[37,38,39,40]}$. The methanol extract was reported to be better than diethyl ether extract ${ }^{[37]}$. Another study also mentioned that the ethanol extract of ancak leaf has antibacterial activity against $S$. dysenteriae $^{[38]}$.

The ethanol extract of $F$. religiosa at doses of 200 and $400 \mathrm{mg} / \mathrm{kg} \mathrm{BW}$ has given to male Wistar rats induced by castor-oil was shown to significantly reduce the incidence of diarrhea. This can be caused by the content of tannins and flavonoids, where these compounds can denature proteins in the mucous ducts, thereby reducing secretion and having an effect on reducing the incidence of diarrhea ${ }^{[41]}$. Ancak leaf also has anti-inflammatory activity, where the inflammatory reaction can be caused by the invasion of bacteria and cytokinins in the colon with the manifestation of dysentery syndrome with diarrhea accompanied by mucus and blood ${ }^{[42]}$.

\section{CONCLUSION}

Treatment of diarrhea can be done with synthetic drugs, but its use needs to be limited so as not to cause unwanted effects. Treatment with herbs today has been intensified, and one of them is by using an herbal approach to Usada. One of the Usada papyrus that explains about the treatment of diarrhea is Usada Tenung Tanya Lara. In this papyrus, Three main plants can be used as agents of diarrhea therapy, namely turmeric (Curcuma longa), banana (Musa paradisiaca), and leaves of ancak (Ficus religiosa). These three plants have been reported to be able to become agents of diarrhea therapy with their respective mechanisms of actions.

\section{CONFLICT OF INTEREST}

No conflict of interest in this paper. This paper was written independently without being affiliated by another party.

\section{ACKNOWLEDGMENTS}

Authors would like to thanks all those who helped write this review article.

\section{REFERENCES}

1. Simadibrata, M.K. Pendekatan Diagnostik Diare Kronik. Di dalam : Sudoyo Aru w et al, editor. Buku Ajar Ilmu Penyakit Dalam. Jilid I Edisi IV. Jakarta: Pusat Penerbitan Departemen Ilmu Penyakit Dalam FK UI; 2006.

2. Centers of Disease Control. Diarrhea: Common Illness, Global Killer. Available from: https://www.cdc.gov/healthywater/p df/global/programs/globaldiarrhea50 8c.pdf. Accessed on 25 Mei 2020; 2019.

3. Tjay, T. H., K. Rahardja. Obat-Obat Penting. Edisi ketujuh. Jakarta: Elex Media Komputindo; 2007.

4. Komarulzaman, A., J. Smits, E. De Jong. Clen Water, Sanitation and Diarrhoea in Indonesia: Effects of Household and Community Factors. Global Public Health 2017; 12(9): 1141-1155.

5. Kementerian Kesehatan RI. Buletin: Situasi Diare di Indonesia. Jakarta: Kemenkes RI; 2011.

6. Manalu, S. M. H. Faktor risiko terjadinya diare di kelurahan hamdan kecamatan medan maimun kota 
medan tahun. [scription]. Medan: Universitas Sumatera Utara; 2015.

7. Kusuma, S.A..F., S.R. Mita, I. Firdayani, R. Mustarichie. Study on the Antibacterial Activity of Fruit Extracts of Klutuk Banana (Musa balbisiana Colla) Against Shigella dysenteriae ATCC 13313. Asian Journal of Pharmaceutical and Clinical Research 2017; 10(7): 220-3.

8. Widoyono. Penyakit Tropis Epidemilogi, Penularan, pencegahan dan pemberantasan (2nd ed.). Jakarta: Erlangga; 2011.

9. Baker, D. E. Loperamide: A Pharmacological Review. Reviews in Gastroenterological Disorders 2007; 7 Suppl. 7: 11-20.

10. Williams, P., J.A. Berkley. Disentery. Available from: https://www.ncbi.nlm.nih.gov/pmc/a rticles/PMC6021764/. Accessed on: 25 May 2020; 2016.

11. Sujarwo, W., I.B.K. Arinasa., I.N. Peneng. Inventarisasi Jenis-Jenis Bambu yang Berpotensi Sebagai Obat Di Kabupaten Karangasem Bali. Jurnal Buletin Kebun Raya. Bali: UPT Balai Konservasi Tumbuhan Kebun Raya "Eka Karya"-Lipi 13(1); 2010.

12. Nala, N. Usada Bali. Denpasar: PT. Upada Sastra; 1992.

13. Susiasta, I.G.B., I.K. Suwidja. Terjemahan dan Kajian Usada Tenung Tanya Lara. Denpasar: Departemen Pendidikan dan Kebudayaan Provinsi Bali; 1992.

14. Hewlings, S.J., D.S. Kalman. Curcumin: A Review of Its' Effects on Human Health. Foods 2017; 6(92): $1-11$.

15. Kocaadam, B., N. Sanlier. Curcumin an Active Component of Tumeric (Curcuma longa) and Its Effects on Health. Critical Reviews in Food Science and Nutrition 2015; 57(13): 2889-2895.
16. Ismail, K., M. Khan, Q. Bukhari, M.H. Dar. Anti-diarrheal Effects of Methanol Extract of Curcuma longa. JBUMDC 2017; 7(3): 174-8.

17. Micucci, M., R. Aldini, M. Cevenini, C. Colliva, S. Spinozzi, G. Roda, et al. Curcuma longa L. as a Therapeutic Agent in Intestinal Motility Disorders and Safety Profile in Mouse. Plos One 2013; 8(11): 1-13.

18. Irshad, S., A. Ashfaq, A. Muazzam, A. Yasmeen. Antimicrobial and AntiProstate Cancer Activity of Turmeric (Curcuma longa L.) and Black Pepper (Piper nigrum L.) used in Typical Pakistani Cuisine. Pakistan Journal Zoology 2017; 49(5): 1665-1669.

19. Oo, KCC, K.K. Khaing. Investigation of Curcuma longa L. and Antidiarrhoeal Activity of Its Rhizome. Universities Research Journal 2014; 6(1): 1- 13.

20. Bele, AA, VM Jadhav, SR Nikam, VJ Kadam. Antibacterial Potential of Herbal Formulation. Research Journal of Microbiology 2009; 4(4): 164-7.

21. IDEXX. Microbiology Guide to Interpreting Minimum Inhibitory Concetration. Available from: https://www.idexx.com/files/microbi ology-guide-interpreting-mic.pdf. Accessed on 30 May 2020; 2019.

22. Rabbani, G.H., T. Teka, B. Zaman, N. Majid, M. Khatun, G.J. Fuchs. Clinical Studies in Presistent Dirrhea: Dietary Management with Green Banana Pectin in Bangladeshi Children. Gastroenterology 2001; 1(121): 554-560.

23. Nwankwo, IU, R.C. Osaro-Mathew. Assessment of the Phytochemical Components of Mangifera indica (leaf) and Musa paradisiaca (roots) extracts and Their Antibacterial Activity Against Some Common Pathogenic Bacteria. Journal of Pharmacy and Biological Sciences 2014; 9(1): 8-11. 
24. Asuquo, E,G., C. E. Udobi. Antibacterial and Toxicity Studies of the Ethanol Extract of Musa paradisiaca Leaf. Cogent Biology 2016; 2(1): 1-10.

25. Yakubu, MT, Q.O Nurudeen, S.S. Salimon, M.O. Yakubu, RO. Jimoh, M.O. Nafiu, M.A. Akanji, A.T.Oladiji, F.E. Williams. Antidiarrhoeal Activity of Musa paradisiaca Sap in Wistar Rats. Hindawi 2015; 1-9.

26. Subagio, M.A., C.N. Salim, Q.P. Srisantoso, Y. Nindita, A.W. Utomo, N. Maharani. Utilization of Banana (Musa paradisiaca L.) Peel as Pectin Source as Antidiarrheal on Castor Oil-Induced Diarrheal Wistar Rats Model. Journal Medicine Sciences 2020; 52(2): 102-107.

27. Kamble, P.B., S. Gawande, TS Pati. Extraction of Pectin from Unripe Banana Peel. International Research Journal of Enggineering and Technology (IRJET) 2017; 4(7): 2259-2264.

28. Khamsucharit, $\mathrm{P}$., K. Laohaphatanalert, P. Gavinlertvatana, K. Sriroth, K. Sangseethong. Characterization of Pectin Extracted From Banana Peels of Different Varieties. Food Science Biotechnol 2018; 27(3): 623-629.

29. Tanaid, R.A.B. Extraction Optimization of Pectin from Unripe Banana (Musa acuminate $\mathrm{x}$ balbisiana var. Cardaba) Peel. International Journal of Food Engineering 2018; 4(4): 308-315.

30. Rashid, SNAA, S.M. Sukri, and R. Aziz. Determination of Pectin Content in Preparation of Banana Peel Chips. Avaliable from: https://www.researchgate.net/publica tion/307138697. Accessed on: 18 June 2020; 2018.

31. Ugbogu, E.A., VC. Ude, I. Elekwa, U.O. Arunsi, C.U. Ikonne, C. Nwakanma.. Toxicological Profile of
The Aqueous-Fermented Extract of Musa paradisiaca in Rats. Avicenna Journal of Phytomedicine 2018; 8(6): 478-87.

32. Kunwar R. M., Bussmann, R. W. Ficus (fig) species in Nepal: a review of diversity and indigenous uses. Lyonia 2006; 11: 85-97.

33. Makhija, IK, I.P. Sharma, D. Khamar. Phytochemistry and Pharmacological Properties of Ficus religiosa: an Overview. Annals of Biological Research 2010; 1(4): 171-180.

34. Chandrasekar, SB, M. Bhanumathy, A.T. Pawar, T. Somasundaram. Phytopharmacology of Ficus religiosa. Pharmacognosy Review 2010; 4(8): 195-201.

35. Bhalerao, S.A., A.S. Sharma. Etnomedicinal, Phytochemical and Pharmacological Profile of Ficus religiosa Roxb. International Journal of Current Microbiology and Applied Sciences 2014; 3(11): 528-538.

36. Hasan, M.R., N. Aktar, M.N. Hasan, M. Shamsuzzaman. Phytochemical Screening From Ficus religiosa Leaves and Determination of Sedative-Hypnotic Activity in Mice By Using Ethyl Alcohol Extract. International Journal of Research in Pharmaceutical and Nano Sciences 2019; 8(3): 116-127.

37. Ramakrishnaiah, G., T. Hariprasad. In-vitro Antimicrobial Activity of Leaves and Bark Extracts of Ficus religiosa (Linn.). Indian Journal of Pharmaceutical and Biological Research 2013; 1(1): 38-44.

38. Aqil, F., I. Ahmad. Broad-spectrum Antibacterial and Antifungal Properties of Certain Traditionally Used Indian Medicinal Plants. World Journal of Microbiology and Biotechnology 2003; 19: 653-7.

39. Rahman, M., A. Khatun, S. Khan, F. Hossain, A.A. Khan. Phytochemical, Cytotoxic and Antibacterial Activity of Two Medicinal Plants of 
Bangladesh. Pharmacology On Line 2014; 1: 3-10.

40. Chavan, A., G. Bedekar, P. Miniyar, V. Gawande. Phytochemical Screening and Antimicrobial Investigation of Ficus religiosa Leaves. Pharmaceutical Chemistry 2019; 1(1): 31-42.

41. Potareddy, M.D. Antiinflamatory and Anti-diarrheal Activity of Alcoholic Extract of Ficus religiosa Stem Bark in Wistar Albino Rats. [thesis]. India: University Nagpur; 2013.

42. Utami, W., H.A. Aziz, I.N. Fitriani, A.T. Zikri, A. Mayasari, D. Nasrudin. In-silico Anti-inflammatory Acticity Evaluations of Some Bioactive Compound From Ficus religiosa Through Molecular Docking Approach. Journal of Physics 2019; 1563(1): 1-9. 